\title{
Narratives of (Mad) Desire
}

Timo Airaksinen (University of Helsinki)

\section{Sub-Optimal Choices are Possible}

Suppose $\mathrm{S}$ chooses $\mathrm{Y}$ when, for $\mathrm{S}, \mathrm{X}$ is better than $\mathrm{Y}$ and $\mathrm{X}$ and $\mathrm{Y}$ both possess positive value for $S$. Is this possible? The answer is in the affirmative if the preference relation does not follow from S's choices, as if post hoc. In other words, it is not the case that $\mathrm{S}$ chooses $\mathrm{X}$ first; and next, we infer that $\mathrm{X}>\mathrm{Y}$. Suppose that this is not the case, or $\mathrm{S}$ deliberates between $\mathrm{X}$ and $\mathrm{Y}$ and forms his preference accordingly. He then chooses against his preferences and desires when he takes Y. This is possible because preference is not the same as choice. Suppose $\mathrm{X}>\mathrm{Y}$ at the time $\mathrm{t}$, and $\mathrm{S}$ decides by tossing a coin and takes $\mathrm{Y}$ at $t+1$. Why would this be impossible? If we say that $X>Y$ logically entails the choice of $X$ by $S$, we run into trouble. Suppose at $t-1 Y>X$, which now entails a choice of Y. However, it did not happen as $\mathrm{S}$ was still deliberating at $\mathrm{t}-1$. Now, at $t$, he is ready; however, as we have seen, nothing makes him actually choose $X$ at $t$ if he does not do so. To repeat the key point: at $t-1$, for $S, Y>X$ and no choice occurred; at $\mathrm{t}, \mathrm{X}>\mathrm{Y}$ and a choice occurs; but it is still possible that at $\mathrm{t}$ no choice occurs as S's deliberation continues. Hence, preference does not entail choice; hence, choice is more or less independent of preference and may be inconsistent with it. Moreover, we cannot say that at $\mathrm{t} S$ finally completed his deliberation so that it could not continue. Deliberations are never complete, fixed or final. On the contrary, they are always open-ended. Then, somehow, we move from deliberation to choice and action. In sum: The preference, $\mathrm{X}>\mathrm{Y}$, is the result of $\mathrm{S}$ 's deliberations at $\mathrm{t}$, just like $\mathrm{Y}>\mathrm{X}$ was at $\mathrm{t}-1$ when no choice occurred. Therefore, preferences alone do not fix the choice at $\mathrm{t}-1$ or at $\mathrm{t}$. If you think otherwise, you probably think of revealed preferences. Otherwise, our choices in time are free, or they are at least nondeterministic. $S$ can choose $\mathrm{Y}$ even when $\mathrm{X}>\mathrm{Y}$ at $\mathrm{t}$. Here diachronic considerations are crucial. $\mathrm{S}$ has his preference at $\mathrm{t}$ and then he makes his choice. One can make suboptimal choices. Hence, we infer that, for $\mathrm{S}, \mathrm{Y}>\mathrm{X}$, but only post hoc.

\section{Mad Desires}

When bad things happen to a person, the implication sometimes is that the person himself is responsible for what happened in the sense that he wanted the bad thing to happen. We typically ascribe a mad intention and desire to such a person. The following typically vengeful third-person comments 
express the key idea: It was his own fault; He is such a masochist; He really got what he wanted; His behavior is so self-destructive; or, He was asking for it. However, we have a hard time understanding what is going on here. Sometimes people do not realize what they want, and then when they get it, they experience anxiety or panic.

You may want to smoke even if the anticipated consequences are personally unacceptable, but that alone is not crucial. The definition of a mad desire and the relevant open choice has two parts:

(i) The agent believes that he cannot accept the personally anticipated (bad) consequences of his choice.

(ii) He would not have chosen had he not personally anticipated these (bad) consequences.

In other words, the occurrence of bad consequences forms only a necessary condition of the existence of the mad desire and the relevant choice. Therefore, smoking may not be a mad desire - the second condition is not normally satisfied in this case. The smoker is ready to take the risk but she would happily smoke risk-free tobacco, too. Sometimes we anticipate unacceptable consequences when we act, but the desire need not be mad. The second counterfactual clause is essential. ${ }^{1}$ Here is a relevant example: I rush in a hurry across a busy road risking my life, and I would do so also when the road is empty. This is not a mad case. Risk taking may be irrational in this case, but that is all. It is a bad risk, without being a mad choice.

According to a formal account of desire, only the desire is important, not the content, or what one actually desires. Acts connect to desires, you may desire anything, and if you get it, you are happy [See: Schroeder 2009: "One approach to well-being holds that a person's well-being stems from the satisfaction of her desires". Also: Plato 2001, 204e]. If you intentionally hurt yourself, you had a "generic pro-attitude" towards such an act [Loar 1981, 87]. If you then experience satisfaction, you are happy. If you get what you want, whatever it might be, you cannot complain; and therefore, you are happy. For example, I may want money - the narration of this desire promises pleasure, love, and respect. Because of them, money makes me happy. As long as these positive descriptions apply, I am happy. However, according to this formal view, it does not matter what those descriptions are. They may as well be something you think are bad things. If I get what I want I am happy, and I may want anything, even self-destruction. The result is satisfaction, which may or may not be similar to happiness proper - whatever that is. We may continue the story as follows. It may be happiness but not after I realize what has happened: satisfaction and happiness come first and then, along with the realization of what has happened, dismay because the consequences of one's choice are now seen as unacceptable. I do not think this is fully convincing.

${ }^{1}$ I am grateful here to Dr Heta Gylling (Helsinki). 
Now, offer $S$ a choice between $X$ and $Y$ when $S$ knows that $X$ is good and $\mathrm{Y}$ is not only sub-optimal but also bad; and suppose that $\mathrm{S}$ chooses $\mathrm{Y}$. As a pure preferential choice, this does not make sense. We may argue that $Y$ really is, in the first person perspective, good for $\mathrm{S}$ regardless of what $\mathrm{S}$ happens to say ${ }^{2}$. However, if we think in terms of the narrative theory of desire, we can say that $\mathrm{S}$ desires $\mathrm{Y}$ even if it was prima facie undesirable for S. S can desire anything for which he is able to form a suitable narrative account, even bad things ${ }^{3}$. Deep down in the depths of the fantasy narrative, Y must have its proper place; and thus, $\mathrm{Y}$ becomes an (aspect of the) intentional object of desire and a happiness-maker. The case of $Y$ shows that contexts tend to be complex and ambiguous; as such, they are difficult to describe and understand. The first and third person accounts may not fit together no matter how hard we try. I cannot understand your choices if you do not tell me about your narrative, and even then I may fail.

As I said, people want something bad to happen to them, or an observer sees it that way. People also desire some goals that may be bad for them subjectively. We may also speak about intrinsically bad things here. It is possible that people want to hurt themselves, when we mean by 'hurting' the real thing and nothing figurative or ironic. In this case when I say 'S wants $Y$ which hurts him', I do not mean that $\mathrm{Y}$ is good for $\mathrm{S}$ because $\mathrm{S}$ chose it; and therefore, hurting becomes a mere third-person ascription. The correct formulation now is, 'I want Y which I believe hurts me'. What I say is that I want to hurt myself, and I know it. Yet, we may not understand how it is possible to say that $S$ wants to hurt himself in this first person perspective. No one should drink strong acid. Its consequences are unacceptable. Such a mad act requires an explanation; and thus, we say the person must have his special reasons. Say, he madly desires love and believes that to drink acid is the only way to get, first, the woman's pity and then her love. Moreover, the person would not have drunk the acid if it had no bad effects on him-when the bad effect was both anticipated and subjectively unacceptable or intolerable.

Such an instrumental explanation emerges rather naturally. The mad desire instrumentally serves a positive end. Here, acid drinking is a means towards the happiness-maker (intentional object) of a desire, which is a fantasy narrative about love. Sometimes people do extreme and irrational things in order to get what they want. They know acid drinking is bad and they say they believe it is necessary in the sense that it is their only available choice; thus, they are ready to suffer. Hence, to drink acid cannot be, as such, a

\footnotetext{
2 For a contrary view, see: Stocker 1979.

${ }^{3}$ Desire is a narrative in the sense that the agent tells herself a story of why she wants, why the object of her desire is attractive and good, and what happens when one gets what she desires. Such a narrative characterizes full and complete desires. Desires lead to action when there is a good reason to make the choice that realizes the desire. See: Airaksinen 2012 .
} 
key happiness-maker in any fantasy narrative. Its occurrence in such a role would poison a good story. Hospitalization, long-term severe pain, and a lifelong handicap do not count when one tells a story about one's own happiness. In this sense, mad desires may look impossible in the first person perspective if the harm does not have an instrumental role. I would not have drunk acid had I not wanted to make an impression on her. This is a mad case as both (i) and (ii) are satisfied when my the motivation is understood instrumentally.

Not all mad choices invite an instrumental explanation. Sometimes a mad act is non-instrumental. This is how it goes. You cannot focus on an isolated intentional object of desire alone; instead, you need to tell the whole story of the desire in question. Sometimes the narrative is instrumental, but only sometimes. Why do motorcyclists drive without glasses, helmet, gloves, leathers, and boots whenever they can? They refuse any protective gear when they legally can. They love their ideas of independence, freedom, and courage in a mad way. This must depend on some strange preferences. Perhaps they cherish the very idea of the risk of mutilation and death in the name of ultimate freedom, courage, and self-expression. Danger is a key element in their self-expression; yet, this is not an instrumental case [see: Airaksinen, Kaalikoski 2001]. There is a clear difference between these two cases: (a) I do not wear a helmet because then I can feel the wind in my hair (instrumental case), and (b) I do not wear a helmet, because free and courageous people do not do so (non-instrumental case). In (b), the person is already free and courageous and his lack of a helmet just points this out. Moreover, in (b) the person would not drive without protective gear if the danger were not there. In (a), danger is unnecessary: if we can do it safely, let us do so. Most mountain climbers use protective gear, but that activity is still dangerous enough to be worthwhile. Total safety makes climbing boring and less desirable. There are many dangerous things we would not do without the danger.

Sudden and uncontrollable impulses, compulsions, and urges explain some strange actions much better that any reference to desires. We do bad things impulsively and we may damage ourselves. This happens, but anomalous impulses do not explain all the cases of mad actions. They may well be as real as the perversions of thought and practical reasoning are, although, we normally deny their motives. It is easy to live in denial. A psychoanalytical theorist would say that a person who wants to get hurt compulsively entertains a trauma-based subconscious thanatic desire. Some theorists offer this as a partial explanation of otherwise unaccountable mental states [see: Davidson 1982]. However, I do not see how it explains them. On the contrary, it just restates, ad hoc, the original problem in mystifying terms. We may then suggest that a person desires harmful things if his mind is twisted enough so that he does not know what he wants. Perhaps he makes errors. As such, the case remains ambiguous. Perhaps the person sees pain and suffering as happiness-makers, which is perverse. It is not easy to understand what kind of 
a fantasy narrative is in question, how one creates, mobilizes, motivates, and tells it. One can hardly communicate it. Nevertheless, references to impulsive or compulsive choices and to missing self-understanding do not explain enough.

\section{Happiness Disappointed}

Let us say that Socrates has a desire to die because he wants his salvation as a martyr, and so his punishment becomes part of his fantasy narrative about the desirability of his own death; therefore, his death is indeed a happiness-maker. It is now a necessary component of the story; hence, $\mathrm{X}$ (martyr) implies $\mathrm{Y}$ (death). This is different from the instrumental and non-instrumental cases I discussed above. It is a logical case: it is impossible to be a martyr without dying first in a typical way. (I suppose death is intolerable, even in this case). The problem is the following: if $X$ makes $S$ happy, why should not $Y$ do it? The answer is this: $\mathrm{Y}$, as such, does not make $\mathrm{S}$ happy, because it is undesirable as such. Y's value is conditional. This means that $Y$ belongs to its own narrative frame just like the original $\mathrm{X}$ does. In its own context, $\mathrm{Y}$ has negative value. Yet, in the full context together with $\mathrm{X}$, we cannot separate $\mathrm{Y}$ from the fantasy narrative of $X$, because the fantasy narrative of $Y$ (death) speaks about bad things that necessarily constitute $\mathrm{X}$ (martyrdom). The Y-narrative has a property that makes it a happiness-maker only in relation to $X$. The narrative of $X$ tells the story of how the sub-narrative of $Y$ contributes to the realization of X. This is a happy idea. It also explains why $\mathrm{Y}$, as such, is not a successful happiness-maker. Alone, it is merely pain and suffering, but together with $\mathrm{X}$, it becomes a (partial) happiness-maker.

Both $\mathrm{X}$ and $\mathrm{Y}$ are happiness-makers when they occur together. However, they have their problems. The narrative account of them may be disappointing, as the Buddhists, Heraclitus, Epicurus, Hobbes, Kant, Nietzsche, Schopenhauer, Simone Weil, and Jacques Lacan say [see: Webster 2005, Ch. 1 "Desire in Western Thought"]. All this leads to the following suggestion. Full happiness is something that is a possible achievement mainly in the thirdperson narrative perspective. I can say that a person is happy when all goes well in her life. In the first person perspective, things look different. What I mean when I say that she is happy is that she should be happy. When I think of my own life, I can also say that I should be happy. Yet, I never should say I am happy. It just looks that way. This allows us to understand the old and familiar saying: Call no one happy before her death. In an honest first person perspective I always remain unsatisfied and, therefore, to some degree unhappy. This is a pessimistic view.

Let me consider two relevant cases and their explanations. I want punishment because of $\mathrm{N}$, where $\mathrm{N}$ is the main point of a fantasy narrative containing all the happiness-making features. Think of the famous death wish 
of convicted murderer Gary Gilmore (1977) ${ }^{4}$ [Mailer 1979]. His feeling of guilt was too much to bear, so that he insisted that they execute him in Utah. It is possible, masochistically, to desire suffering when suffering makes one happy, that is, when $\mathrm{N}$ exists. Nevertheless, even this wish must be disappointing, as no $\mathrm{N}$ is not quite what it could and should have been. I am unhappy independently of whether I want intentional pain or pleasure. When a person hurts herself, this will be a source of disappointment, too. Think of religious zealots who want to hurt themselves to please their gods. They mercilessly debase, mutilate, torture, flog, and starve themselves [see: Westermarck 1939, Ch. IX "Asceticism"]. This is their non-instrumental quest for their holy identity; to try to please their gods is an instrumental motivation. Their favorite narrative says that such an identity pleases their gods; and hence, it ought to emerge. At the same time, the intentional objects of their desires are mad; they must be mad or otherwise they could not please the gods. Gods want suffering and allow no games or play. However, no self-torture is enough to fulfill the relevant desire, which is to worship the gods in the right way. They can go on forever and never be satisfied and happy. Their gods always want more. Perhaps a zealot should try self-deception about this. Happiness often, or even mainly, results from self-deception [see: Mele 2001, 95f]. Certainly, the most dramatic conclusion concerns the gods who never get what they want from their holy worshippers. They never suffer enough, and they may even enjoy their ordeals. The cruel gods will be disappointed in the end. One expects the gods of being angry with the humans, as the believers never suffer enough in the right way. The zealots say, however, that they would never flog themselves if it did not actually hurt and harm them.

No self-torture or other mad desire is good, per se, from the point of view of a rational agent himself. Yet, a person's background story may require that the intentional object of his desire be mad in a sense that it is unacceptable as such in the first person perspective, because otherwise it could not fit its key role in the happy fantasy narrative. This person really wants to hurt himself, because he thinks that this is a necessary condition of the success of his personal happiness-maker. Hence, the bad thing is bad even for the agent himself, but it has a role in his own narrative account of the relevant happiness-makers that he cannot skip. If he wants to be happy, he must desire the mad thing that, for this reason alone, cannot be good per se, from his own considered first person point of view.

We have now reached the conclusion to the effect that the intentional objects of desire in my own first person perspective may be either positive or negative things. The only requirement was that the person expects happiness to follow when one reaches the goal. This depends on the relevant fantasy narrative that may contain many different kinds of elements and their

\footnotetext{
${ }^{4}$ Gilmore wants his death because it is the only way out of his intolerable life.
} 
evaluations. Its actualization makes the person expect happiness. Even pain is good when it fits certain fantasy narratives of desire. For example, I know I need to suffer when I try to please the gods of my religion who then promise me eternal bliss. I would not please them if I did not suffer.

\section{Satisfying the Demon of Morality}

A Kantian intuition is that we cannot accept the idea that someone treats us as mere objects [see: Weil 2007, 156-157: "Being under compulsion, the plaything of another is unendurable for a human being"]. Suppose you are accused and sentenced without anyone telling you what your alleged crime is, just like they used to do in ancient China and Japan and in the fiction of Franz Kafka, as if you were a mere object. This is unjust caprice. Perhaps, such an event cannot figure in any possible background fantasy narrative as the intentional object of desire and, thus, take the role of a happiness-maker. This may well be true, and if it is true, this peculiar fact must depend on the use of the term 'unjust'. It refers to the type of pain and suffering that is unbearable in a special sense. This is, perhaps, a limiting case of what happiness-makers can be. Some kind of suffering is either too much or of a wrong type. Why could we not desire unjust treatment in the hands of the law? For instance, I am certain, unlike anyone else, that the law-courts of my country are corrupt. I want them to treat me unjustly, because only then can I confirm my belief. I say happily, 'I told you they are corrupt' (this is an instrumental case). I want to prove a point, and I am ready to suffer to know and to show what is true. I want to tell the truth to others as well, but I do not know any other way. Here, very strong personal resistance to such a treatment is to be expected. I desire the unjust treatment, but at the same time, I resist it. If I did not have my pet moral beliefs, I could not desire my unjust treatment. The key elements of the fantasy narrative are dependent on the full story and its plot and cannot make sense without them.

It sounds intuitive to require that the narrative whole, unlike some of its components, has to be ultimately positive in nature - after all, it tells a happy story. Accordingly, any of the narrative fragments of the story can be negative, but the final entity and its tone must be positive. This sounds plausible. However, the final conclusion is always unpredictable, and so it is merely a wish that our first person perspective fantasy narratives would be nice, wise, good, pleasant, and positive, that is, happy. They are ugly, vague, fleeting, fantasized, ambiguous, and ultimately self-contradictory; therefore, it is difficult to know. Gloomy and pessimistic persons may entertain negative narratives that bypass their interest in personal happiness. These people are happy to be unhappy, which does not make much sense. Hence, it is difficult to say whether they are happy or unhappy. It is no wonder that we can find evidence for the Systematic Imprudence Thesis: "Human beings are 
systematically prone to make a wide range of serious errors in matters of personal welfare" [Haybron 2008, 227]. About how ridiculously happy people may claim they are, see [Brooks 2008].

This is to suggest that the (final) fantasy narratives of desire may end up being negative and unhappy. If you support the romantic approach to life, you may accept the speculations above. Horror is pleasant and pain pleases you. The abyss of doom is what you want. Perhaps all the truly interesting fantasy narratives lead, in the end, to the dark abyss of evil [Berlin 2001; Berlin 1994]. You like the idea that the end of the world will soon be here. You welcome it. Of course, any thinker who supports the values of the Enlightenment will find such ideas hard to accept. Notice that Plato, Socrates, and Kant appear in this perspective at least as moderate romanticists. One possibility is to argue against the Romanticism that such stories are meaningful only in the figurative and fictional sense. No one likes them as facts. Alternatively, we say that such stories do not make sense in the first person perspective. I cannot want to live them through, although they are fine ideas to play with in one's imagination. Yet, such narratives are endlessly appealing.

Independently of romanticism, it is of course possible and even common that one's wish-related fantasy narratives are mad and, in this sense, negative. A free-floating, empty wish motivates weakly; one does not really want it. Hence, we may express all kinds of moods and visions that create possible worlds that are far away and thus, not accessible from our factual lifeworld. We often play with our negative desires in this sense. However, what should we say about real desires? We have been discussing desires and wants that focus on their intentional objects that are happiness-makers embedded in complex fantasy narratives. As I said above, happy fantasy narratives should have their over-all positive tone. However, the following story makes this optimistic picture questionable.

A man wants to avenge the murder of his family by killing the murderer. He knows that after doing so he will regret it and must spend the rest of his life in prison. He does not expect to be happy there. Nevertheless, he considers the murder as his moral duty, or perhaps this is a duty of heroic virtue founded on his image of himself as a strong, proud, noble, just, and courageous type of man [Casey 1990, Ch. 2; MacIntyre 1981, Ch. 10]. His fantasy narrative focuses now on duty and its cruel demands, not happiness in any ordinary sense. Kant provides an example when he writes that sometimes it is honorable to die rather than to accept another more lenient punishment. He writes, "[I]f all alike were sentenced to death; the man of honor would be punished mildly in terms of his sensibilities and the scoundrel severely in terms of his. On the other hand, if both were sentenced to convict labor the man of honor would be punished too severely and the other too mildly for his vile action" [Kant 1996, 107]. We can hardly say that even for a virtuous man 
death is better than hard labor. On the contrary, we can say that death is worse, but at the same time it is the desired alternative in terms of his duty of personal virtue. Here is another case of $\mathrm{X}>\mathrm{Y}$ for $\mathrm{S}$, when $\mathrm{Y}$ is chosen by $\mathrm{S}$.

Now, the intentional object is murder, which satisfies the demands of the personal fantasy narrative. However, such an intentional object is not a relevant happiness-maker. He may be happy when he kills, but this does not mean that he will be happy in the end. In other words, to quote an unforgettable line from Fred Zinnemann's film, An Act of Violence (1948): "I may not be happy but I get my kicks". Of course, the avenging moral person does not expect to be happy. He wants to do his duty, or to get his moral kicks. Therefore, these intentional objects are not happiness-makers. Moreover, the overall tone of the fantasy narrative is clearly negative, even tragic in the romantic sense. In moral philosophy, virtue may lead to happiness, as Socrates says, but it does not happen here. If we consider the Kantian deontology, happiness and duty may not meet - as Kant himself makes clear [Kant 1964, 61, 89-90]. No duty guarantees the moral agent's overall happiness for Kant. The moral avenger may be satisfied, but he is not happy. Now, it is better to be unhappy and satisfied than unhappy and unsatisfied. We see that sometimes desire aims at its satisfaction more than to the agent's happiness. In other words, satisfaction of desire does not logically entail happiness. In some cases, satisfaction leaves you unhappy, but this is strange unhappiness because you cannot regret it; you are satisfied. It is a special type of (un)happiness. However, 'satisfaction' is too thin and an abstract concept to be of much interest, unlike 'happiness', which is a thick concept [Williams 1985, 128].

\section{Literature}

Airaksinen, T. 2012. "Happiness and Desire". Homo Oeconomicus Vol. 29 Issue 3: 393-412.

Airaksinen, T., Kaalikoski, K. 2001. "Instrumental Rationality". In: Pryer, G., Peter, G. P. (eds.) The Contextualization of Rationality. Paderborn: Mentis.

Berlin, I. 1994. The Magus of the North: J. G. Hamann and the Origins of Modern Irrationalism. New York: Farrar, Straus \& Giroux.

Berlin, I. 2001. Roots of Romaticism. Princeton: Princeton University Press.

Brooks, A. C. 2008. Gross National Happiness. New York: Basic Books.

Casey, J. 1990. Pagan Virtues. Oxford: Oxford University Press.

Davidson, D. 1982. "Paradoxes of Irrationality". In: Wollheim, R., Hopkins, J. (eds.) Philosophical Essays on Freud. Cambridge: Cambridge University Press.

Haybron, D. M. 2008. The Pursuit of Unhappiness. Oxford: Oxford University Press. 
Kant, I. 1964. Groundwork of the Metaphysics of Morals. Trans. H. J. Paton. New York: Harper.

Kant, I. 1996. The Metaphysics of Morals. Trans. M. Gregor. Cambridge: Cambridge University Press.

Loar, B. 1981. Mind and Meaning .Cambridge: Cambridge University Press.

MacIntyre, A. 1981. After Virtue. Notre Dame: Notre Dame Press.

Mailer, N. 1979. The Executioner's Song. London: Little Brown.

Mele, A. 2001. Self-Deception Unmasked. Princeton: Princeton University Press.

Plato. 2001. Symposium. Trans. S. Bernadete. Chicago: University of Chicago Press.

Schroeder, T. 2009. "Desire". In: Edward N. Zalta (ed.). The Stanford Encyclopedia of Philosophy (Winter 2009 Edition). URL = http://plato.stanford.edu/archives/win2009/entries/desire/.

(Accessed 9/26/12)

Stocker, M. 1979. "Desiring the Bad: An Essay in Moral Psychology". Journal of Philosophy Vol. 76: 738-53

Webster, D. 2005. Philosophy of Desire in the Buddhist Pali Canon. London: Routledge.

Weil, S. 2007. Gravity and Grace. Trans. E. Crawford \& M. von der Ruhr. London: Routledge.

Westermarck, E. 1939. Christianity and Morals. London: Kegan Paul.

Williams, B. 1985. Ethics and the Limits of Philosophy. Cambridge: Harvard University Press. 
Timo Airaksinen (University of Helsinki)

\title{
Narratives of (Mad) Desire
}

\begin{abstract}
Satisfied desires make you happy. Desires are fantasy narratives a person tells about her life and goals. They focus on intentional objects that are happiness-makers for the person: to achieve them is supposed to make one happy. Normally, such objects are good things and their context is seen in a positive manner. However, the goals may also be hurtful, as the person herself sees it. These are, at least sometimes, mad desires. To explain them, it is not enough to say that they are impulsive and irrational, unconscious, or that they are good in disguise. I explain what this means and give some examples. I also consider the thesis that satisfaction of desire is less than full happiness, which may well be true. This becomes clear when we think of moral choices.
\end{abstract}

Keywords: desire, mad desire, narratives, well-being, happiness, morality, rationality

Ethics in Progress (ISSN 2084-9257). Vol. 4 (2013). No. 2. pp. 7-17. 